\title{
KUALITAS TERJEMAHAN TINDAK TUTUR EKSPRESIF DALAM NOVEL BREAKING DOWN (AWAL YANG BARU) KARYA STEPHENIE MEYER
}

\author{
Hari Nugraha \\ UIN Sunan Gunung Djati Bandung \\ J1. A.H. Nasution 105 Cibiru Kota Bandung \\ Email: harinugraha518@gmail.com
}

\begin{abstract}
Abstrak
Penerjemahan tindak tutur merupakan kegiatan penerjemahan yang menarik mengingat proses pemahaman pesan harus dikaitkan dengan konteks (situasi tutur) yang melingkupinya. Tindak tutur atau disebut dengan speech act merupakan salah satu kajian yang didefinisikan sebagai suatu ujaran yang mengandung tindakan. Penelitian ini ditulis dengan tujuan untuk menganalisis speech act yang digunakan dalam novel Breaking Down dan kualitas penerjemahan (keakuratan, keterbacaan dan keberterimaan)-nya. Tahapan dalam melakukan penelitian yang termasuk dalam kualitatif deskriptif ini, di antaranya pengumpulan data, analisis data, mencari model, kuesioner, dan penyusunan kesimpulan berdasarkan data tanpa membuat generalisasi data. Penelitian ini menemukan 159 data tuturan yang diklasifikasikan ke dalam 19 jenis tindak tutur ekspresif. Ditinjau dari segi kualitas terjemahan, tindak tutur ekspresif dalam novel terjemahan dengan judul Awal yang Baru sudah menunjukkan kualitas dari sisi keakuratan, keberterimaan, dan keterbacaannya.

Kata kunci: Kualitas Terjemahan, Tindak Tutur Ekspresif, Breaking Down
\end{abstract}

\begin{abstract}
Translation of speech acts is an interesting activity considering the process of understanding the message consisting in the text which have relation with the context (speech situation). Speech acts are parts of many linguistic fields defined as actions that contain utterances. This study was done to analyze the speech acts used in the novel entitled Breaking Down and the quality of the translation based on accuracy, readability and acceptance. Steps of study included in this descriptive qualitative study were data collection, data analysis, data classification, questionnaire distribution, and conclusion making based on data without making data generalizations. The study found 159 data classified into 19 types of expressive speech acts. It showed that translation of the novel, particularly expressive speech act had been translated properly. The translation had high qualities based on terms of accuracy, acceptance, and readability.
\end{abstract}

Keywords: Translation Quality, Expressive Speech Act, Breaking Down 
KUALITAS TERJEMAHAN TINDAK TUTUR EKSPRESIF DALAM NOVEL BREAKING DOWN (AWAL YANG BARU) KARYA STEPHENIE MEYER

\section{PENDAHULUAN}

Salah satu jenis karya sastra yang berkembang pesat adalah karya sastra terjemahan karena topiknya beragam dan alur ceritanya 'fluktuatif' (https://www.goodreads.com/topic/show/90 241-penerjemah) Rasa ingin tahu, sebagai pembaca tentang budaya bangsa lain di luar Indonesia menjadi dorongan utama untuk meningkatnya perkembangan karya sastra terjemahan. Di samping itu, muncul kebosanan dengan novel novel dalam negeri yang hanya membahas tentang cinta yang dramatis, terkesan cengeng, dan mudah ditebak(https://www.goodreads.com/topic/s how/90241-penerjemah).

Penerjemahan karya sastra bukanlah sesuatu yang mudah. Menerjemahkan karya sastra jauh lebih rumit dibandingkan dengan menerjemahkan teks lainnya. Banyak unsur yang harus diperhatikan dalam proses penerjemahannya, sebagai contoh adalah aspek budaya dimana bahasa sumber dan bahasa sasaran memiliki konsep budaya yang berbeda.

Dalam menerjemahkan karya sastra yang memiliki perbedaan sudut pandang budaya, penerjemahan menjadi sebuah keahlian khusus dimana itu dibutuhkan untuk menjaga kesatuan pesan yang ada dalam sebuah teks. Termasuk didalamnya adalah dalam hal makna yang terkandung di dalamnya atau unsur prakmatik didalam sebuah teks.

Peran seorang penerjemah adalah membawa gagasan yang ada dalam Bsu untur dialihbahasakan kedalam Bsa, sehingga tidak terjadi reduksi makna ataupun penyimpangan makna dalam sebuah konteks budaya dari bahasa sumber (Bsu) dan bahasa sasaran (Bsa), juga hasil dari penerjemahan bisa berterima dalam masyarakat Bsa. Salah satu yang memberi sumbangan paling besar dalam ranah penerjemahan adalah pragmatik.

Ilmu pragmatik menjadi penting dalam hal penerjemahan karena pragmatik merupakan telaah mengenai relasi antara bahasa dengan konteks yang merupakan dasar dalam pemahaman bahasa (Levinson 1983). Dalam hal penerjemahan, hal ini digunakan untuk menerjemahkan berbagai macam tuturan yang mengandung maksud tersendiri dalam berbagai macam situasi. Salah satunya adalah tindak tutur atau disebut dengan speech act yang merupakan salah satu kajian yang didefinisikan sebagai suatu ujaran yang mengandung tindakanhal ini dikatakan oleh Yule (1996: 47).

Speech act menunjukkan bahwa setiap ujaran atau tuturan dalam sebuah komunikasi mengandung maksud dan tujuan yang bisa mempengaruhi orang lain. Atas dasar paparan ini, pendekatan teori yang digunakan dalam penelitian ini adalah 
pendekatan pragmatik, dimana dalam pemilihan dan penentuan data penelitian ini, semua tindak tutur ekspresif dalam Bsu dan Bsa dari novel "breaking down" dan terjemahannya “awal yang baru”. Data yang terkumpul dan divalidasi selanjutnya dianalisis dengan menggunakan teori pragmatik, yaitu teori tindak tutur oleh Searle dan Yule.

Beberapa penelitian terkait analisis tindak tutur dengan menggunakan pendekatan pragmatik menjadi inspirasi maupun referensi dalam melakukan penelitian ini antara lain penelitian yang sudah dilakukan oleh Irta Fitriana (2014) yang fokus pada jenis dan fungsi tindak ilokusi ekspresif yang terdapat pada novel tersebut. Selanjutnya, penelitian yang relevan adalah sebuah penelitian yang ditulis oleh Adventina Putranti (2007). Dalam penelitiannya, penulis memfokuskan kajiannya pada tindak tutur ekspresif yang terdapat dalam teks terjemahan film American Beauty dan keterkaitannya dengan penerjemahan. Penelitian ini menjadi salah satu penelitian yang relevan karena adanya penilaian kualitas penerjemahan yang terletak pada aspek kesepadanan dan keberterimaan.

Selain itu penelitian dari Ardiana Nuraeni (2008) menjadi satu referensi yang signifikan karena memberikan sajian penelitian yang sangan spesifik dan terfokus pada dalah satu tindak tutur expresif yaitu mengeluh. Dalam penelitian ini sudah memeliki klasifikasi dalam hal teknik penerjemahan untuk mengetahui kualitas penerjemahan. Dalam hubungannya dengan penelitian ini, masih banyak aspek tentang tindak tutur yang belum disentuh dalam peneltian ini sebagai contoh adalah ilokusi ekspresif lainnya.

\section{METODE}

Penelitian ini termasuk dalam penelitian deskriptif yang bertujuan untuk mendeskripsikan sebuah fenomena. Surakhmad (dalam Abdurrahman dan Soejono, 1999: 22) menerangkan bahwa pelaksanaan metode-metode deskriptif tidak terbatas hanya sampai pada tahap pengumpulan dan penyusunan data, tetapi meliputi analisis dan interpretasi tentang arti data tersebut, atas dasar tesebut penelitian ini menggukanan pendekatan kualitatif. Hal ini berdasarkan pada pendapat Sutopo (2002: 35) meyatakan bahwa penelitian kualitatif menitik beratkan pada data yang berupa kata-kata, kalimat, atau gambar yang memiliki arti lebih daripada sekedar angka atau frekuensi.

Data dalam penelitian ini terbagi menjadi dua jenis, yaitu data primer dan data sekunder. Data primer dalam penelitian ini adalah semua tuturan yang termasuk tindak tutur ekspresif yang terdapat dalam novel Breaking Down yang diterbitkan oleh Hachette Book Group USA tahun 2008 dan 


\section{KUALITAS TERJEMAHAN TINDAK TUTUR EKSPRESIF DALAM NOVEL BREAKING DOWN (AWAL YANG BARU) KARYA STEPHENIE MEYER}

terjemahannya Awal yang Baru yang diterbitkan oleh PT Gramedia Pustaka Utama pada tahun 2009, serta data yang diperoleh dari hasil kuesioner dan wawancara dengan para rater untuk menilai tingkat keakuratan, keberterimaan, dan keterbacaan.

Sedangkan data sekunder adalah segala informasi yang terkait dengan dalam novel Breaking Down dan terjemahannya Awal yang Baru baik mengenai penulis maupun reviews terhadap novel tersebut yang ditulis oleh institusi tertentu atau para kritikus sastra.

Teknik purposive sampling digunakan dalam penelitian ini untuk mencari dan memilih, serta memilah data utama berupa tindak ilokusi ekspresif yang ada dalam novel Breaking Down dan terjemahannya Awal yang Baru.

Teknik analisis dokumen, kuesioner, dan wawancara secara mendalam digunakan untuk mengumpulkan data, sedangkan dalam menganalisis dokumen, peneliti membaca secara menadalam novel yang menjadi objek kajian dalam penelitian untuk mendapatkan data berupa klasifikasi data tentang tuturan ekspresif, dan kuisoner digunakan untuk mendapatkan informasi tentang kualitas penerjemahan yang meliputi 3 kriteria keakuratan, kerterbacaan, dan keberterimaan berdasarkan skala dalam instrument penilaian kualitas penerjemahan dari (Nababan, Nuraeni, dan Sumardiono, 2012: 50-51)

Pada penelitian ini, penilaian kualitas terjemahan dilakukan oleh rater ahli dan rater awam. Rater ahli dipilih untuk menilai tingkat keakuratan dan keberterimaan terjemahan.

Pemilihan rater ahli adalah dengan beberapa kriteria: (1) berpendidikan minimal S-1 jurusan bahasa Inggris atau sastra Inggris (2) memiliki pengalaman di bidang guiding tourist untuk menunjukkan bahwa mereka sering bersentuhan bahasa Inggris, (3) memiliki keterkaitan dengan novel.

Pemilihan rater awam pun juga didesain sedemikian rupa untuk mendapatkan hasil yang lebih objektif. Kualifikasi rater awam dalam penelitian ini adalah memiliki kemampuan dalam bahasa Indonesia yang baik dan memiliki kecintaan terhadap novel

Pemilihan rater dalam penelitian ini memiliki tujuan dalam hal keabsahan data sehingga data yang didapatkan bisa menjadi lebih objektif dan representatif. Selain itu, penlitian ini mengunakan trianggulasi data dan metode untuk mendapatkan hasil yang representatif dan valid. Berdasarkan paparan di atas, penelitian ini bertujuan untuk mengkaji kualitas terjemahan tindak tutur ekspresif secara menyeluruh yang 
mencakup tiga aspek, yakni keterbacaan, keakuratan, dan keberterimaan.

\section{PEMBAHASAN}

\section{a. Tindak tutur ekspresif}

Temuan jenis tindak tutur ekspresif temuan jenis tindak tutur ekspresif ini dilakukan dengan menganalisis novel Breaking Down dan terjemahannya Awal yang Baru. Analisis yang dilakukan berdasarkan kriteria pemilihan data yakni satuan lingual tuturan atau kalimat yang merupakan tindak tutur ekspresif. Berdasarkan kriteria tersebut, dapat ditemukan sebanyak 138 data dalam penelitian ini.

Tahap berikutnya, keseluruhan data yang ditemukan dikelompokkan menurut jenis tindak tutur ekspresif. Hasil temuan dalam novel Breaking down, menemukan 19 jenis tindak tutur ekspresif dari keseluruhan 139 data, antara lain menyalahkan, menyindir, berharap, menyetujui, memprotes, salam perpisahan, mengejek, salam, meminta maaf, menyesal, menuduh, mengumpat, berterima kasih, bersimpati, bersyukur, memuji, mengeluh, membantah, ucapan, dan selamat, dengan komposisi dan persentase sebagai berikut: berteri makasih 15 data $(9,43 \%)$, memprotes 10 data $(6,29 \%)$, menyetujui 7 data $(4,40 \%)$, meyalahkan 9 data $(5,66 \%)$, menyindir 6 data $(3,77 \%)$, meminta maaf 10 data $(6,29 \%)$, memuji 18 data $(11,32 \%)$, salam perpisahan 11 data $(6,92 \%)$, berharap 8 data $(5,03 \%)$, mengumpat 6 data $(3,77 \%)$ menyesal 7 data $(4,40 \%)$, bersimpati 7 data (4,40\%), bersyukur 10 data (6,29\%), mengejek 8 data $(3,03 \%)$, menuduh 7 data (4,40\%), mengeluh 4 data (2,52\%), membantah 6 data $(3,77 \%)$, ucapan selamat 5 data $(3,14 \%)$, salam 5 data $(3,14 \%)$, Berikut tabel hasil temuan data tindak tutur ilokusi ekspresif pada novel Breaking Down (Tabel 1).

\section{a. Penilaian Tingkat Kualitas Terjemahan Ada tiga aspek penting untuk melakukan penilaian tingkat kualitas terjemahan, yakni keakuratan,} keberterimaan, dan keterbacaan (Nababan, 2010: 44- 45). Suatu terjemahan dikatakan berkualitas apabila pengalihan pesan Bsu ke Bsa akurat, berterima sesuai kaidah- kaidah Bsa, dan mudah dipahami oleh pembaca sasaran.

Pada penelitian ini, penilaian kualitas terjemahan dilakukan oleh rater ahli dan rater awam. Rater ahli dipilih untuk menilai tingkat keakuratan dan keberterimaan terjemahan, sedangkan untuk penilaian tingkat keterbacaan dinilai oleh rater awam.

Adapun dalam penilaian kualitas terjemahan ini rater yang ditunjuk sebanyak 3 orang untuk tiap aspek kualitas terjemahannya. Secara teknis, penilaian kualitas terjemahan ini dengan menggunakan kuesioner kepada setiap rater. 


\section{KUALITAS TERJEMAHAN TINDAK TUTUR EKSPRESIF DALAM NOVEL BREAKING DOWN (AWAL YANG BARU) KARYA STEPHENIE MEYER}

Selanjutnya, para rater diharapkan mampu memberikan nilai sesuai dengan parameter yang telah ditentukan. Apabila dalam penilaian kualitas ini menemui permasalahan seperti perbedaan signifikan, peneliti akan

Table 1 Klasifikasi Tindak Tutur Ekspresif

\begin{tabular}{|c|c|c|c|}
\hline $\begin{array}{c}\text { Jenis } \\
\text { Tindak } \\
\text { Tutur } \\
\text { Ekspresif }\end{array}$ & $\begin{array}{c}\text { Kode } \\
\text { Temuan } \\
\text { Data }\end{array}$ & $\sum$ & $\%$ \\
\hline $\begin{array}{l}\text { Berteri } \\
\text { makasih }\end{array}$ & $\begin{array}{l}107,115, \\
010,071, \\
147,093, \\
133,028, \\
154,144, \\
070,148, \\
128,125, \\
124\end{array}$ & 15 & 9.43 \\
\hline Memprotes & $\begin{array}{l}127,007, \\
030,073, \\
016,024, \\
134,092, \\
155,027\end{array}$ & 10 & 6.29 \\
\hline Menyetujui & $\begin{array}{l}108,114, \\
078,074, \\
015,138, \\
140\end{array}$ & 7 & 4.40 \\
\hline $\begin{array}{l}\text { Meyalahka } \\
\mathrm{n}\end{array}$ & $\begin{array}{l}021,013, \\
033,094, \\
120,087, \\
091,002, \\
101\end{array}$ & 9 & 5.66 \\
\hline Menyindir & $\begin{array}{l}082,136, \\
112,104, \\
055,037,\end{array}$ & 6 & 3.77 \\
\hline $\begin{array}{l}\text { Meminta } \\
\text { maaf }\end{array}$ & $\begin{array}{l}001,156, \\
067,116, \\
151,057, \\
096,131, \\
103,061\end{array}$ & 10 & 6.29 \\
\hline Memuji & $\begin{array}{l}025,009, \\
075,113, \\
038,077, \\
003,008,\end{array}$ & 18 & $\begin{array}{c}11.3 \\
2\end{array}$ \\
\hline
\end{tabular}

melakukan wawancara pada rater.

Wawancara yang dilakukan adalah dalam bentuk diskusi perihal data yang dipermasalahkan.

\begin{tabular}{|c|c|c|c|}
\hline & $\begin{array}{l}005,081 \\
, 122, \\
080,022, \\
076,158, \\
102,041, \\
121\end{array}$ & & \\
\hline $\begin{array}{l}\text { Salam } \\
\text { perpisahan }\end{array}$ & $\begin{array}{l}\text { 050, 053, } \\
118,152, \\
006,097, \\
023,045, \\
062,143, \\
085,\end{array}$ & 11 & 6.92 \\
\hline Berharap & $\begin{array}{l}064,052, \\
111,072, \\
026,117, \\
043,065\end{array}$ & 8 & 5.03 \\
\hline Mengumpat & $\begin{array}{l}\text { 044, 034, } \\
095,105 \\
046,137\end{array}$ & 6 & 3.77 \\
\hline Menyesal & $\begin{array}{l}123,047, \\
058,089, \\
066,012, \\
083\end{array}$ & 7 & 4.40 \\
\hline Bersimpati & $\begin{array}{l}036,031, \\
084,048, \\
086,032, \\
059\end{array}$ & 7 & 4.40 \\
\hline Bersyukur & $\begin{array}{l}109,051, \\
132,068, \\
106,020, \\
079,145, \\
119,141\end{array}$ & 10 & 6.29 \\
\hline Mengejek & $\begin{array}{l}069,035 \\
029,088, \\
126,040 \\
099,017\end{array}$ & 8 & 5.03 \\
\hline Menuduh & $\begin{array}{l}139,039, \\
049,153, \\
146,060, \\
159\end{array}$ & 7 & 4.40 \\
\hline Mengeluh & $\begin{array}{l}056,018, \\
142,090\end{array}$ & 4 & 2.52 \\
\hline
\end{tabular}




\begin{tabular}{|l|l|c|c|} 
& $\begin{array}{l}054,042, \\
\text { Membantah } \\
157,110, \\
129,100\end{array}$ & 6 & 3.77 \\
\hline $\begin{array}{l}\text { Ucapan } \\
\text { selamat }\end{array}$ & $\begin{array}{l}004,098, \\
019,130, \\
149\end{array}$ & 5 & 3.14 \\
\hline $\begin{array}{l}\text { Memberi } \\
\text { salam }\end{array}$ & $\begin{array}{l}011,014, \\
135,150, \\
063\end{array}$ & 5 & 3.14 \\
\hline \multicolumn{2}{|c|}{ Jumlah } & 159 & 100 \\
\hline
\end{tabular}

\section{1) Keakuratan}

Penilaian keakuratan berhubungan dengan kesepadana antara teks Bsu dan Bsa. Dengan kata lain, pesan pada teks Bsu harus tersampaikan secara akurat ke dalam Bsa. Untuk menilai tingkat keakuratan hasil terjemahan, langkah yang dilakukan adalah dengan menggunakan instrumen tingkat keakuratan dengan parameter sebagai berikut (Nababan, 2010: 44-45):

\section{a) Parameter akurat}

Makna kata, istilah teknis, frasa, klausa, kalimat atau teks Bsu dialihkan secara akurat ke dalam Bsa; sama sekali tidak terjadi distorsi makna.

\section{b) Parameter kurang akurat}

Sebagian besar makna kata, istilah teknis, frasa, klausa, kalimat atau teks Bsu sudah dialihkan secara akurat ke dalam Bsa. Namun, masih terdapat distorsi makna atau terjemahan makna ganda (taksa) atau makna yang dihilangkan, yang mengganggu keutuhan pesan.

\section{c) Tidak akurat}

Makna kata, istilah teknis, frasa, klausa, kalimat atau teks Bsu dialihkan secara tidak akurat ke dalam Bsa atau dihilangkan.

Tabel 2 Data Penelitian

\begin{tabular}{|c|l|}
\hline $\begin{array}{c}\text { Tindak } \\
\text { Tutur } \\
\text { Ekspersif }\end{array}$ & \multicolumn{1}{|c|}{ Data } \\
\hline menyetujui & $\begin{array}{l}\text { Bsu: "Sure-nobody is } \\
\text { going to believe me if I } \\
\text { don't get proof." }\end{array}$ \\
$\begin{array}{l}\text { Bsa: "Tentu tidak ada } \\
\text { yang bakal percaya } \\
\text { kalau aku tidak punya } \\
\text { buktinya " }\end{array}$ \\
\hline
\end{tabular}

Dalam ujaran di atas, Edward mengekspresikan perasaannya yang menyetujui bahwa tak aka nada yang percaya jika dia tak memili bukti yang nyata.

\begin{tabular}{|l|l|}
\hline \multirow{2}{*}{ memprotes } & $\begin{array}{l}\text { Bsu: "Yeah, who cares } \\
\text { what they think" }\end{array}$ \\
$\begin{array}{l}\text { Bsa: "Yeah, masa } \\
\text { bodoh dengan pikiran } \\
\text { mereka" }\end{array}$ \\
\hline
\end{tabular}

Dalam percakapan diatas, tokoh bela memprotes tentang apa yang akan dia lakukan dimana pernikahan dia dengan laki laki yang dia cintai bukanlah sebuah. kesalahan.

\begin{tabular}{|l|l|}
\hline \multirow{2}{*}{ memprotes } & $\begin{array}{l}\text { Bsu: "Don’t start this } \\
\text { again," } \\
\text { Bsa:"Jangan mulai } \\
\text { lagi," }\end{array}$ \\
\hline
\end{tabular}

Dalam data diatas, ekspresi bela dalam memprotes apa yang telah dilakukan oleh Edward, dimana hal itu membuat dia terganggung dan marah.

\begin{tabular}{|l|l|}
\hline \multirow{2}{*}{ menuduh } & $\begin{array}{l}\text { Bsu: "Are you trying to } \\
\text { ditch me?" }\end{array}$ \\
& $\begin{array}{l}\text { Bsa: "Kau berusaha } \\
\text { mencampakkanku, ya?" }\end{array}$ \\
\hline
\end{tabular}


KUALITAS TERJEMAHAN TINDAK TUTUR EKSPRESIF DALAM NOVEL BREAKING DOWN (AWAL YANG BARU) KARYA STEPHENIE MEYER

\begin{tabular}{|l|l|}
\hline $\begin{array}{l}\text { Dalam data diatas, dapat dilihat bahwa } \\
\text { Edward mengekspresikan perasaannya } \\
\text { dengan dasar prasangka bahwa dia akan } \\
\text { ditinggalkan. }\end{array}$ \\
\hline bersimpati & $\begin{array}{l}\text { Bsu: "Definitely } \\
\text { staying," } \\
\text { Bsa:"Kalau begitu, jelas } \\
\text { aku akan tetap di sini," }\end{array}$ \\
\hline $\begin{array}{l}\text { Dalam data diatas, bela } \\
\text { mengekspresikan simpatinya untuk } \\
\text { tetapi tinggal, hal ini didasari pada } \\
\text { perasaannya yang bersimpati kepada } \\
\text { sebuah keadaan. }\end{array}$ \\
\hline
\end{tabular}

Dalam penelitian ini, hasil yang diperoleh mengenai penilaian kualitas terjemahan tindak tutur ekspresif pada novel Breaking down adalah sebanyak 149 data merupakan terjemahan yang akurat, 10 data kurang akurat dan tidak ada data dinyatakan tidak akurat, seperti yang tersaji dalam tabel berikut:

Dapat dikatakan bahwa sebagian besar tindak tutur ekspresif dalam novel ini diterjemahkan secara akurat. Hanya sebagian kecil saja yang diterjemahkan secara kurang akurat, yakni 10 data dan tidak ada data yang teridentifikasi sebagai terjemahan tidak akurat. Dengan demikian, tuturan ekspresif dalam novel Breaking down merupakan terjemahan yang baik dengan indikator tingkat keakuratan yang tinggi (Tabel 3).

Table 3 Jumlah Terjemahan Akurat, Kurang Akurat, dan tidak Akurat

\begin{tabular}{|c|c|c|}
\hline $\begin{array}{c}\text { Tingkat } \\
\text { Keakuratan }\end{array}$ & $\begin{array}{c}\text { Jumlah } \\
\left(\sum\right)\end{array}$ & $\%$ \\
\hline Akurat (1) & 149 & 93 \\
\hline
\end{tabular}

\begin{tabular}{|c|c|c|} 
Kurang Akurat (2) & 10 & 6 \\
\hline Tidak Akurat (3) & 0 & 0 \\
\hline Jumlah & 159 & 100 \\
\hline
\end{tabular}

Table 4 Jumlah Terjemahan Berterima, Kurang Berterima, dan Tidak Berterima

\begin{tabular}{|l|c|c|}
\hline $\begin{array}{l}\text { Tingkat } \\
\text { Keberterimaan }\end{array}$ & $\begin{array}{c}\text { Jumlah } \\
\left(\sum \mathbf{~}\right)\end{array}$ & \% \\
\hline Berterima (3) & 157 & 99 \\
\hline Kurang Berterima (2) & 2 & 1 \\
\hline Tidak Berterima (3) & 0 & 0 \\
\hline \multicolumn{1}{|c|}{ Total } & $\mathbf{1 1 8}$ & $\mathbf{1 0 0}$ \\
\hline
\end{tabular}

\section{2) Keberterimaan}

Keberterimaan didefinisikan sebagai derajat kealamiahan suatu teks penerjemahan terhadap kaidah dan budaya dalam Bsa. Penilaian tingkat keberterimaan hasil terjemahan dilakukan melalui distribusi kuesioner pada tiga rater ahli untuk menilanya. Ada tiga kriteria dalam penilaian tingkat keberterimaan suatu teks terjemahan sebagai berikut:

a) Terjemahan berterima manakala penerjemahan terasa alami, penggunaan istilah teknis, frasa, klausa, dan kalimat sudah sesuai dengan kaidah- kaidah dalam Bsa.

b) Terjemahan kurang berterima memiliki beberapa indikasi yaitu sebagian besar teks Bsa sudah terasa alami, namun masih terdapat masalah dalam hal istilah atau kesalahan gramatikal.

c) Terjemahan tidak berterima dapat diketahui apabila terjemahan tidak alamiah, atau terasa seperti karya 
terjemahan karena penggunaan istilah yang dipilih tidak lazim digunakan dan tidak akrab terdengar bagi pembaca.

Table 5 Jumlah Terjemahan dengan Tingkat Keterbacaan Tinggi, Sedang, dan Rendah

\begin{tabular}{|l|c|c|}
\hline $\begin{array}{c}\text { Tingkat } \\
\text { Keterbacaan }\end{array}$ & $\begin{array}{c}\text { Jumlah } \\
\left(\sum\right)\end{array}$ & $\%$ \\
\hline Tinggi (3) & 159 & $100 \%$ \\
\hline Sedang (2) & - & - \\
\hline Rendah (3) & - & - \\
\hline Total & $\mathbf{1 5 9}$ & $\mathbf{1 0 0 \%}$ \\
\hline
\end{tabular}

Pada penelitian ini, data yang ditemukan sebanyak 157 data atau $(96,61 \%)$ termasuk dalam kategori terjemahan berterima, 2 data $(3,39 \%)$ termasuk dalam terjemahan kurang berterima dan tidak ada data yang diterjemahkan dengan tidak berterima. Data- data yang masuk kategori berterima, kurang berterima dan tidak berterima dapat dilihat dalam tabel berikut:

Dapat dikatakan bahwa hamper semua tindak tutur ekspresif dalam novel ini diterjemahkan dengan berterima kedalam Bsa dan hanya sebagian kecil saja yang diterjemahkan secara kurang berterima. Dengan demikian, tuturan ekspresif dalam novel Breaking down merupakan terjemahan yang baik dengan indikator tingkat keberterimaan yang tinggi (Tabel 4).

\section{3) Keterbacaan}

Tingkat keterbacaan dilakukan dengan menilai bagaimana suatu teks terjemahan dapat dipahami oleh pembaca Bsa.
Instrumen yang digunakan dalam penilaian tingkat keterbacaan ini adalah melalui kuesioner, yang berisikan bilaman ; (1) tingkat keterbacaan tinggi apabila data tergolong mudah dipahamidengan mudah oleh pembaca, (2) tingkat keterbacaan sedang apabila terjemahan dapat dipahami oleh pembaca, namun ada sebagian tertentu yang diperlu dibaca ulang untuk memahaminya, (3) tingkat keterbacaan rendah apabila terjemahan sulit dipahami oleh pembaca sasaran. Dengan kata lain, pembaca tidak dapat memahami teks terjemahan tersebut (Nababan, 2010: 4445).

Dari keseluruhan data tuturan ekspresif dalam novel Breaking downini, termasuk terjemahan dengan tingkat keterbacaan tinggi dimana secara keseluruhan data dapat dipahami oleh pembaca.

Novel terjemahan tersebut memiliki tingkat keterbacaan yang sangat tinggi dimana secara keseluruhan tindak tutur ekspresif dalam novel tersebut dapat berterima kepada pembaca Bsa (Tabel 5)

\section{KESIMPULAN}

Dalam penelitian ini ditemukan 19 jenis tindak tutur ekspresif dari keseluruhan 159 data, antara lain menyalahkan, menyindir, berharap, menyetujui, memprotes, salam perpisahan, mengejek, salam, meminta maaf, menyesal, menuduh, 


\section{KUALITAS TERJEMAHAN TINDAK TUTUR EKSPRESIF DALAM NOVEL BREAKING DOWN (AWAL YANG BARU) KARYA STEPHENIE MEYER}

mengumpat, berterima kasih, bersimpati, bersyukur, memuji, mengeluh, membantah, ucapan selamat dan memberi salam.

Dari segi kualitas tenerjemahan yang didasarkan pada indikator keakuratan keterbacaan dan keberterimaan menunjukan bahwa novel terjemahan Breaking Down dengan judul Awal yang Baru sudah termasuk dalam terjemahan yang berkualitas dimana hampir seluruh data tindak tutur ekspresif dalam penelitian ini telah diterjemahkan secara sangat baik.

Dari segi keakuratan terdapat 10 data teridentifikasi kurang akurat karena masih terngiang ngiang kepada budaya Bsu bukan Bsa akan tetapi dalam penerapannya rater masih bisa memahami secara lengkap hasil penerjemahan tersebut. Dari sisi keterbacaan seluruh isi novel terjemahan bisa bisa dibaca dengan sempurna oleh pembacannya, dan untuk sisi keterbacaan, dari data yang ditemukan hanya terdapat 2 yang kurang berterima, hal ini kemungkinan adalah karena keterbatasan Bsa dalam diksi kesejajarannya. Akan tetapi semua data yang ada menunjukan bahwa novel terjemahan ini adalah product yang berkualitas bila dilihat dari instrument yang digunakan dalam penelitian.
DAFTAR PUSTAKA

Adventina Putranti. 2007. Kajian Terjemahan Tindak Ilokusi Ekspresif dalam Teks Terjemahan Film American Beauty.

Ardiana Nuraeni. 2008. Perbandingan Terjemahan Tindak Tutur Mengeluh dalam Film Bad Boys II yang ditayangkan di stasiun televisi dan $V C D$.

Daru Singgih Kuncara M. R. Nababan, dan Sri Samiati 2013 "Analisis Terjemahan Tindak Tutur Direktif Pada Novel The Godfather Dan Terjemahannya Dalam Bahasa Indonesia.

Deka, Singgih. 2011. Kualitas Terjemahan. Kompasiana, Opini. edisi 26 December 2011

Kridalaksana, Harimurti. 2001. Kamus Linguistik (Edisi ketiga). Jakarta: PT Gramedia Pustaka Utama.

Leech, Geoffrey. 1993. Prinsip- prinsip Pragmatik (diterjemahkan oleh Oka). Jakarta. Balai Pustaka

Levinson. Stephen. 1983.Pragmatics. London. Cambridge University Press.

Moleong, L. 2000. Metodologi Penelitian Kualitatif. Bandung: Rosda karya.

Molina, L., \& Albir, H. 2002. Translation Techniques Revisited: A Dynmic and Functionalist Approach. Meta Journal des Tranducteur/ Meta:Translators' Journal (XLLVII) No.4, hal. 498- 512.

Nababan, M.R. 2003. Teori Menerjemah bahasa Inggris. Yogyakarta. Pustaka Belajar

Nababan, Rudolf, dkk. 2012. Pengembangan Model Penilaian Kualitas Terjemahan. UNS. Kajian Linguistik dn Sastra, Vol. 24. No. 1. Edisi Juni 2012: 39- 57

Nababan, Rudolf, dkk. 2012. Pengembangan Model Penilaian Kualitas Terjemahan UNS. Kajian Linguistik dn Sastra, Vol. 24. No. 1. Edisi Juni 2012: 39- 57 
Newmark, Peter. 1988. A Textbook of Translation. Singapore: Prentice Hall.

Nida, Eugene, A., \& Taber, Charles R. 1974.

The Theory and Practice of Translation. Leiden: E.J. Brill.

Nugraheni, Yunita. 2011. Implikatur Percakapan Tokoh Wanita dan Tokoh Laki- laki dalam Film Harry Potter and The Goblet of Fire. Jurnal LENSA. Unimus. Vol 1 No 2, Juli Desember 2011. Hal 183- 193.

Nurhaniah, Yayuk Anik. 2008. Terjemahan Kalimat Tanya pada Percakapan di dalam Novel Remaja "Dear No Body" ke dalam Bahasa Indonesia.

Rahardi, K. 2005. Pragmatik: Kesantunan Imperatif Bahasa Indonesia. Jakarta: Erlangga

Rustono, 1999. Pokok- pokok Pragmatik.Semarang: CV. IKIP Semarang Press

Searle, John. R. 1969. Speech Act: An Essay on the Philosophy of Language. New York. Cambridge University Press.

Sutopo, H.B. 2002. Metodologi Penelitian Kualitatif: Dasar teori dan terapannya dalam penelitian (Qualitative research methodology: Basic theories and their application to research). Surakarta: Sebelas Maret University Press.

Tarigan, Henry Guntur. 1986. Pengajaran Pragmatik. Bandung: Angkasa

Wafa, Hosnol. 2013. "Kajian Terjemahan Tindak Tutur Ilokusi Direktif dalam Komik Baby Blues Siaga Satu Anak Pertama Karya Rick Kirkman dan Jerry Scott dan Pengaruhnya terhadap Kualitas Terjemahan".

Wafa, Hosnol. 2013. "Kajian Terjemahan Tindak Tutur Ilokusi Direktif dalam Komik Baby Blues Siaga Satu Anak Pertama Karya Rick Kirkman dan Jerry Scott dan Pengaruhnya terhadap Kualitas Terjemahan". Pascasarjana UNS.

Yule, George. 1996. Pragmatics. Oxford: Oxford University Press 